\title{
Development of the Financial Markets in Turkey in Comparison with the EU Countries
}

\author{
Prof. Dr. Sudi Apak (Beykent University, Turkey) \\ Asst. Prof. Dr. Mehmet Fatih Bayramoğlu (Bülent Ecevit University, Turkey)
}

\begin{abstract}
The Turkish financial sector, especially the Turkish banking sector, demonstrates a growth tendency in recent years. Although this growth is observed to be steady, it has not reached a sufficient volume and the sources of growth are not healthy. In this study, the dimensions of the said growth in the Turkish financial sector are analyzed in comparison with the EU member countries, which are also the members of OECD, with respect to the competitiveness features of the countries and financial centers, banking sectors of the countries and the capital markets of the countries. The study presents an evaluation of the current situation with a special focus on Istanbul - a city planned to be a global financial center.
\end{abstract}

\section{Introduction}

Banking sector constitutes the basic dynamics of growth in the financial sector of Turkey which has gained the tendency to grow after going through a difficult period of restructuring after the banking crises in 1999 and 2001. However, Turkey progressed slowly in capital markets and thus this sector lagged behind the banking sector. Conversely, with the stability gained in the economic and fiscal policies and the new regulations in the field of law such as the Turkish Commercial Code and the Capital Markets Law, the development of the Turkish financial sector has become more stable compared to past periods. These developments have been reflected positively on several reports, which are prepared on a global scale and compare certain countries or financial centers according to various criteria, in terms of Turkey in general and of Istanbul in particular.

However, since the basic dynamics of growth in the banking sector are based on consumer loans, credit cards and transaction fees rather than real sector and exports, continuity of the said growth and development in the sector is not guaranteed. Analysis of the sources of the developments in the capital markets demonstrates that especially the publicly traded banks, a small number of companies outside the financial sector and government debt instruments are effectual.

In the following sections of the present study, the developments in the Turkish financial sector will be presented in comparison with the EU member countries which are also the members of OECD. Section 2 is devoted to the comparison of the competitiveness features of the countries and financial centers, Section 3 is devoted to the comparison of the banking sectors of the countries and Section 4 presents the comparison of the capital markets of the countries.

\section{Comparison of the Competitiveness Features of the Countries and Financial Centers}

The course of the development of macroeconomic indicators of a country is parallel to the ease of doing business in that country. In this context, 185 countries were compared in terms of ease of doing business in the "Doing Business Report" published periodically by the World Bank (WB) and the International Finance Corporation (IFC). As seen in Table 1, when Turkey is compared with the EU countries included in the Report, it is observed that Denmark, United Kingdom and Finland occupied the first three ranks and that Turkey ranked 69th in the overall scoring and had a position higher than the positions of Greece, Romania and Czech Republic. Turkey needs to progress in terms of ease of doing business. It is obvious that Turkey has a potential in terms of ease of doing business when the positive developments in the Turkish economy, the improvements in the Turkish Commercial Code, incentives developed regularly in order to support domestic and foreign investors and the improvement and development investments in the infrastructure are considered (World Bank \& IFC, 2014).

Another indicator that shows the development level of the countries in terms of global trade is the "Index of Economic Freedom" calculated and publicly announced by The Heritage Foundation. According to the Index, calculated within the scope of 181 countries by taking into consideration two basic variables as "Trade-Weighted Average Tariff Rate" and "Non-Tariff Barriers", Ireland, Denmark and United Kingdom occupied the first three ranks and Turkey ranked 64th in the overall scoring and had a position higher than the positions of Portugal, France, Italy and Greece (Heritage Foundation, 2014).

According to the Global Competitiveness Index announced annually by World Economic Forum, by the end of 2014, the most competitive countries were Finland, Germany and Sweden. Turkey ranked 44th in the overall scoring and had a position higher than the positions of Czech Republic, Italy, Portugal, Hungary, Romania, Slovakia and Greece (WEF, 2014). 


\begin{tabular}{|l|c|l|c|l|c|}
\hline \multicolumn{1}{|c|}{ Doing Business } & Rank & Economic Freedom & Rank & Global & Rank \\
\hline Denmark & 5 & Ireland & 9 & Finland & 3 \\
\hline United Kingdom & 10 & Denmark & 10 & Germany & 4 \\
\hline Finland & 12 & United Kingdom & 14 & Sweden & 6 \\
\hline Sweden & 14 & Netherlands & 15 & Netherlands & 8 \\
\hline Ireland & 15 & Germany & 18 & United Kingdom & 10 \\
\hline Germany & 21 & Finland & 19 & Denmark & 15 \\
\hline Netherlands & 28 & Sweden & 20 & Austria & 16 \\
\hline Austria & 30 & Austria & 24 & Belgium & 17 \\
\hline Portugal & 31 & Czech Republic & 26 & France & 23 \\
\hline Belgium & 36 & Belgium & 35 & Ireland & 28 \\
\hline France & 38 & Spain & 49 & Spain & 35 \\
\hline Poland & 45 & Poland & 50 & Poland & 42 \\
\hline Slovakia & 49 & Hungary & 51 & Turkey & 44 \\
\hline Spain & 52 & Slovakia & 62 & Czech Republic & 46 \\
\hline Hungary & 54 & Romania & 64 & Portugal & 49 \\
\hline Italy & 65 & Turkey & 69 & Hungary & 51 \\
\hline Turkey & 69 & Portugal & 70 & Romania & 63 \\
\hline Greece & 72 & France & 86 & Slovakia & 76 \\
\hline Romania & 73 & Italy & 119 & Greece & 78 \\
\hline Czech Republic & 75 & Greece & & 91 \\
\hline
\end{tabular}

Table 1. Competitiveness Features of the Countries According to the Results of Various Studies Source: World Bank \& IFC, 2014; the Heritage Foundation, 2014; WEF, 2014.

\begin{tabular}{|c|c|c|c|c|c|}
\hline \multicolumn{3}{|c|}{ Foreign Direct Investment to GDP (2011) } & \multicolumn{3}{|c|}{ Venture Capital Availability (2011) } \\
\hline Rank & Country & $\%$ & Rank & Country & $\%$ \\
\hline 3 & Belgium & 17.36 & 4 & Sweden & 4.38 \\
\hline 9 & Ireland & 6.02 & 10 & Finland & 3.91 \\
\hline 14 & Denmark & 4.43 & 11 & Netherlands & 3.78 \\
\hline 16 & Portugal & 4.33 & 12 & United Kingdom & 3.77 \\
\hline 20 & Austria & 3.37 & 19 & Belgium & 3.53 \\
\hline 21 & Hungary & 3.35 & 24 & Germany & 3.16 \\
\hline 23 & Poland & 2.95 & 27 & Austria & 3.01 \\
\hline 30 & Czech Republic & 2.51 & 37 & France & 2.77 \\
\hline 32 & Sweden & 2.25 & 38 & Slovak Republic & 2.76 \\
\hline 34 & United Kingdom & 2.23 & 41 & Denmark & 2.61 \\
\hline 35 & Slovak Republic & 2.23 & 43 & Turkey & 2.51 \\
\hline 37 & Turkey & 2.04 & 44 & Spain & 2.50 \\
\hline 38 & Netherlands & 2.04 & 45 & Romania & 2.50 \\
\hline 39 & Spain & 1.97 & 47 & Czech Republic & 2.41 \\
\hline 46 & France & 1.47 & 49 & Ireland & 2.38 \\
\hline 48 & Romania & 1.41 & 50 & Poland & 2.36 \\
\hline 49 & Italy & 1.32 & 52 & Portugal & 2.28 \\
\hline 50 & Germany & 1.13 & 57 & Hungary & 2.10 \\
\hline 55 & Greece & 0.60 & 59 & Italy & 2.03 \\
\hline 59 & Finland & 0.02 & 61 & Greece & 1.83 \\
\hline
\end{tabular}

Table 2. Foreign Direct Investment and Venture Capital Availability Features of the Countries Source: WEF, 2012.

While direct investments constitute a significant portion of the foreign capital inflow to Turkey, another major portion consists of portfolio investments. Portfolio investments which represent hot money are known to flow rather into closed economies. The main reason for this is the high return potential in money and capital markets. Therefore, high transaction volumes of foreign capital are observed both in interest-based instruments and instruments based on profit share.

In Table 2, the ratios of foreign direct investments of 62 selected countries to GDP are listed in the Financial Development Report published by World Economic Forum (WEF) in 2012. As can be seen in Table 2, the ratio of foreign direct investments to GDP in Turkey remained at a low level with $2.04 \%$ by 2011. Among the selected countries, Belgium, Ireland and Denmark occupied the first three ranks and Turkey had a position higher than the positions of Netherlands, Spain, France, Romania, Italy, Germany, Greece and Finland, although this was lower than the expected ratio. 
When the countries in Table 2 are evaluated in terms of venture capital availability, Sweden, Finland and the Netherlands occupied the first three ranks. Turkey, on the other hand, demonstrated a performance lower than the expected performance and ranked 43rd in the overall scoring. However, it is observed that the position of Turkey was higher than the positions of many EU Countries such as Spain, Romania, Czech Republic, Ireland, Poland, Portugal, Hungary, Italy and Greece.

It is observed in Table 3 that when the countries under investigation are evaluated on the basis of financial centers, there is a decline in the financial centers of the EU countries as of March 2012 according to the March 2011-March 2014 GFC Index. Vienna is observed to be the only EU member financial center that continued to rise steadily. Istanbul, on the other hand, is the only financial center that has risen steadily since March 2011.

\begin{tabular}{|c|c|c|c|c|c|c|c|c|c|c|c|}
\hline \multirow[b]{2}{*}{ Centre } & \multicolumn{2}{|c|}{ March 2011} & \multirow[b]{2}{*}{ Centre } & \multicolumn{2}{|c|}{ March 2012} & \multirow[b]{2}{*}{ Centre } & \multicolumn{2}{|c|}{ March 2013} & \multirow[b]{2}{*}{ Centre } & \multicolumn{2}{|c|}{ March 2014} \\
\hline & Rank & Rating & & Rank & Rating & & Rank & Rating & & Rank & Rating \\
\hline London & 1 & 775 & London & 1 & 781 & London & 1 & 807 & \begin{tabular}{|l} 
London \\
\end{tabular} & 2 & 784 \\
\hline Frankfurt & 14 & 654 & Frankfurt & 13 & 681 & Frankfurt & 10 & 703 & Frankfurt & 11 & 709 \\
\hline Paris & 20 & 637 & Paris & 22 & 650 & Vienna & 20 & 685 & Vienna & 19 & 696 \\
\hline Edinburgh & 29 & 600 & Stockholm & 25 & 645 & Paris & 26 & 670 & Stockholm & 30 & 683 \\
\hline Amsterdam & 32 & 593 & Amsterdam & 33 & 637 & Stockholm & 32 & 657 & Paris & 36 & 672 \\
\hline Stockholm & 33 & 592 & Vienna & 34 & 636 & Amsterdam & 34 & 655 & Amsterdam & 46 & 652 \\
\hline Madrid & 37 & 588 & Copenhagen & 36 & 634 & Milan & 37 & 652 & Istanbul & 47 & 651 \\
\hline Brussels & 41 & 581 & Edinburgh & 37 & 632 & Copenhagen & 45 & 643 & Milan & 48 & 650 \\
\hline Milan & 41 & 581 & Helsinki & 42 & 626 & Brussels & 46 & 641 & Brussels & 57 & 630 \\
\hline Vienna & 43 & 576 & Brussels & 47 & 620 & Madrid & 51 & 635 & Warsaw & 60 & 626 \\
\hline Copenhagen & 46 & 571 & Madrid & 49 & 617 & Helsinki & 52 & 634 & Copenhagen & 61 & 623 \\
\hline Prague & 55 & 547 & Milan & 52 & 609 & Edinburgh & 54 & 632 & Edinburgh & 64 & 620 \\
\hline Helsinki & 56 & 546 & Warsaw & 54 & 606 & \begin{tabular}{|l} 
Istanbul \\
\end{tabular} & 57 & 626 & \begin{tabular}{|l|} 
Madrid \\
\end{tabular} & 71 & 604 \\
\hline Warsaw & 59 & 538 & Prague & 56 & 602 & Prague & 61 & 611 & Helsinki & 72 & 592 \\
\hline Lisbon & 64 & 525 & Istanbul & 61 & 590 & Warsaw & 63 & 608 & Prague & 75 & 589 \\
\hline Istanbul & 71 & 494 & Lisbon & 68 & 575 & Lisbon & 76 & 552 & Budapest & 77 & 560 \\
\hline Budapest & 72 & 468 & Budapest & 74 & 552 & Budapest & 78 & 541 & Lisbon & 80 & 536 \\
\hline Athens & 73 & 457 & Athens & 77 & 468 & Athens & 79 & 473 & Athens & 83 & 423 \\
\hline
\end{tabular}

Table 3. Development Tendencies of the Financial Centers (March 2011-March 2014) Source: GFCI, March 2011-2014.

According to the March 2014 Report of GFCI and the grouping study conducted according to the connectivity, diversity and speciality/depth criteria, the global financial centers are Amsterdam, Frankfurt, London, Madrid and Milan. Istanbul, on the other hand, was evaluated as a transitional diversified financial center together with Vienna and outpaced many important financial centers such as Copenhagen, Edinburgh, and Stockholm.

It is seen that Istanbul obtained the positive results of planned work performed with the aim of becoming a financial center. It seems likely that in the future Istanbul will rise in the GFC Index and be one of the global financial centers.

\begin{tabular}{|c|c|c|c|c|}
\hline & Broad \& Deep & Relatively Broad & Relatively Deep & Emerging \\
\hline & Global Leaders & Global Diversified & Global Specialists & Global Contenders \\
\hline \multirow[t]{2}{*}{ Global } & $\begin{array}{c}\text { Amsterdam } \\
\text { Frankfurt } \\
\text { London } \\
\text { Paris }\end{array}$ & Madrid & - & Milan \\
\hline & $\begin{array}{l}\text { Established } \\
\text { Transitional }\end{array}$ & $\begin{array}{l}\text { Transitional } \\
\text { Diversified }\end{array}$ & $\begin{array}{l}\text { Transitional } \\
\text { Specialists }\end{array}$ & $\begin{array}{l}\text { Transitional } \\
\text { Contenders }\end{array}$ \\
\hline \multirow[t]{2}{*}{ Transitional } & $\begin{array}{c}\text { Brussels } \\
\text { Prague }\end{array}$ & $\begin{array}{c}\text { Istanbul } \\
\text { Vienna }\end{array}$ & $\begin{array}{c}\text { Copenhagen } \\
\text { Edinburgh }\end{array}$ & - \\
\hline & Established Players & Local Diversified & Local Specialists & Evolving Centers \\
\hline Local & $\begin{array}{l}\text { Budapest } \\
\text { Lisbon } \\
\text { Stockholm }\end{array}$ & Warsaw & $\begin{array}{c}\text { Athens } \\
\text { Helsinki }\end{array}$ & - \\
\hline
\end{tabular}

Table 4: Development Profile of the Financial Centers according to the GFCI March 2014 Report Source: GFCI, March 2011-2014. 


\section{Comparison of the Banking Sectors of the Countries}

One of the leading indicators of the level of development in the banking sector is the ratio of the banking sector assets to GDP. The ratio of the banking sector assets to GDP is an indicator that provides information about the openness of the banking sector and reveals the weight of bank financing in the economy. As can be seen in Table 5, the ratios of the countries except Poland, Romania, Slovakia and Turkey are observed to be very high. These data show that the banking sector in Turkey still has a closed structure and the banks in Turkey has a role smaller than many EU countries in achieving GDP. This ratio, which is expected to be above $100 \%$, is seen to reach this level only by the end of 2012 in Turkey.

\begin{tabular}{|r|r|r|r|r|r|r|r|r|r|r|r|r|r|r|r|r|r|r|r|r|}
\hline Year & AUT & BEL & CZE & DEN & FIN & FRA & GER & GRE & HUN & IRL & ITA & NL & POL & POR & RO & SVK & ESP & SWE & UK & TR \\
\hline $\mathbf{2 0 0 7}$ & 323 & 389 & 112 & 427 & 171 & 376 & 312 & 173 & 112 & 877 & 220 & 379 & 75 & 260 & 58 & 106 & 285 & 253 & 486 & 70 \\
\hline $\mathbf{2 0 0 8}$ & 375 & 370 & 106 & 467 & 215 & 396 & 318 & 194 & 120 & 962 & 236 & 374 & 72 & 280 & 60 & 101 & 313 & 272 & 481 & 66 \\
\hline $\mathbf{2 0 0 9}$ & 375 & 341 & 118 & 497 & 233 & 401 & 310 & 207 & 140 & 1024 & 247 & 388 & 88 & 309 & 74 & 89 & 328 & 322 & 572 & 85 \\
\hline $\mathbf{2 0 1 0}$ & 342 & 322 & 121 & 483 & 266 & 405 & 332 & 224 & 128 & 992 & 245 & 382 & 88 & 324 & 75 & 88 & 327 & 308 & 541 & 89 \\
\hline $\mathbf{2 0 1 1}$ & 337 & 325 & 116 & 478 & 335 & 420 & 326 & 222 & 114 & 839 & 257 & 403 & 84 & 336 & 67 & 84 & 339 & 295 & 559 & 94 \\
\hline $\mathbf{2 0 1 2}$ & 344 & 313 & 136 & 512 & 338 & 431 & 335 & 247 & 125 & 774 & 292 & 451 & 101 & 366 & 66 & 91 & 377 & 323 & 539 & 106 \\
\hline
\end{tabular}

Table 5. Banking Sector Assets/GDP Ratios of the Countries Source: Euro Banking Association, 2013; BRSA, December 2012.

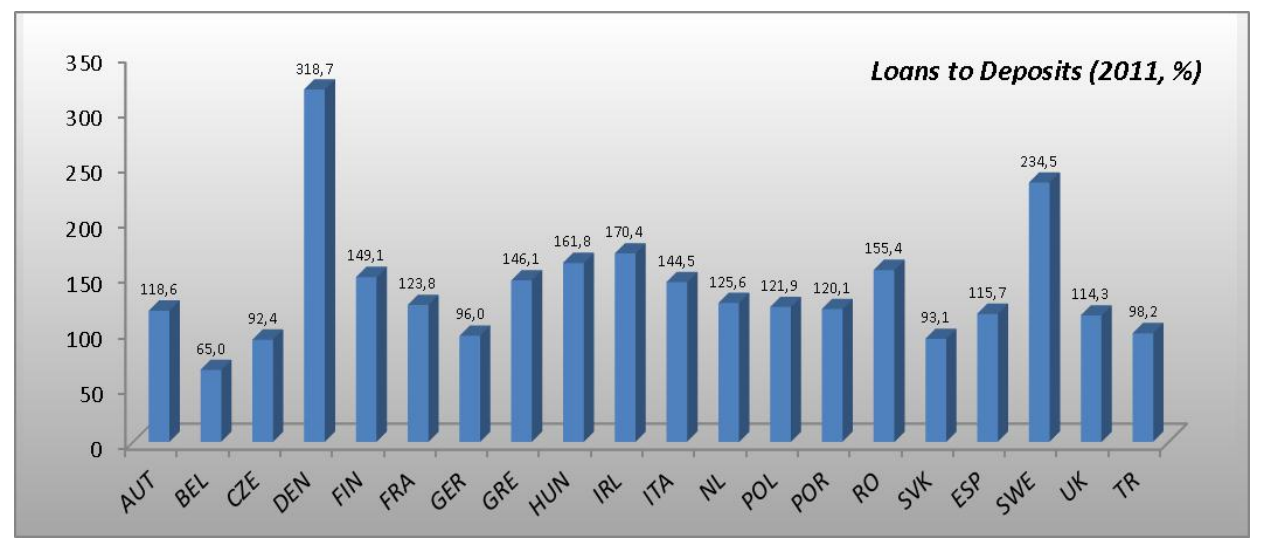

Graph 1. Loan to Deposit Ratio in the Banking Sector (2011) Source: Euro Banking Association, 2013.

\begin{tabular}{|l|c|r|r|}
\hline \multicolumn{1}{|c|}{ Country } & Cost to Income & RoE & Interbank Market Dependence \\
\hline Austria & -72.1 & 1.5 & 23.4 \\
\hline Belgium & -65.7 & 1.4 & 11.4 \\
\hline Czech Republic & -46.2 & 13.7 & 9.3 \\
\hline Germany & -70.5 & 2.2 & 24.6 \\
\hline Denmark & -66.2 & 0.6 & 11.5 \\
\hline Spain & -51.5 & 0.1 & 13.0 \\
\hline Finland & -54.0 & 8.1 & 20.9 \\
\hline France & -66.3 & 5.6 & 9.9 \\
\hline UK & -60.9 & 4.2 & 5.8 \\
\hline Greece & -61.7 & N/A & 10.5 \\
\hline Hungary & -58.3 & -7.9 & 0.0 \\
\hline Ireland & -40.8 & -11.1 & 9.4 \\
\hline Italy & -65.0 & -13.0 & 13.8 \\
\hline Netherlands & -60.5 & 6.2 & 10.1 \\
\hline Poland & -51.7 & 12.3 & 8.1 \\
\hline Portugal & -61.5 & -4.1 & 14.6 \\
\hline Romania & -55.2 & 1.2 & 23.2 \\
\hline Sweden & -58.3 & 10.6 & 0.0 \\
\hline Slovakia & -49.5 & 11.1 & 4.1 \\
\hline Median EU-19 & $\mathbf{- 6 0 . 5}$ & $\mathbf{1 . 8}$ & $\mathbf{1 0 . 5}$ \\
\hline Turkey & 74.0 & 14.0 & 13.0 \\
\hline
\end{tabular}

Table 6. Various Indicators about the Banking Sector Source: Euro Banking Association, 2013. 


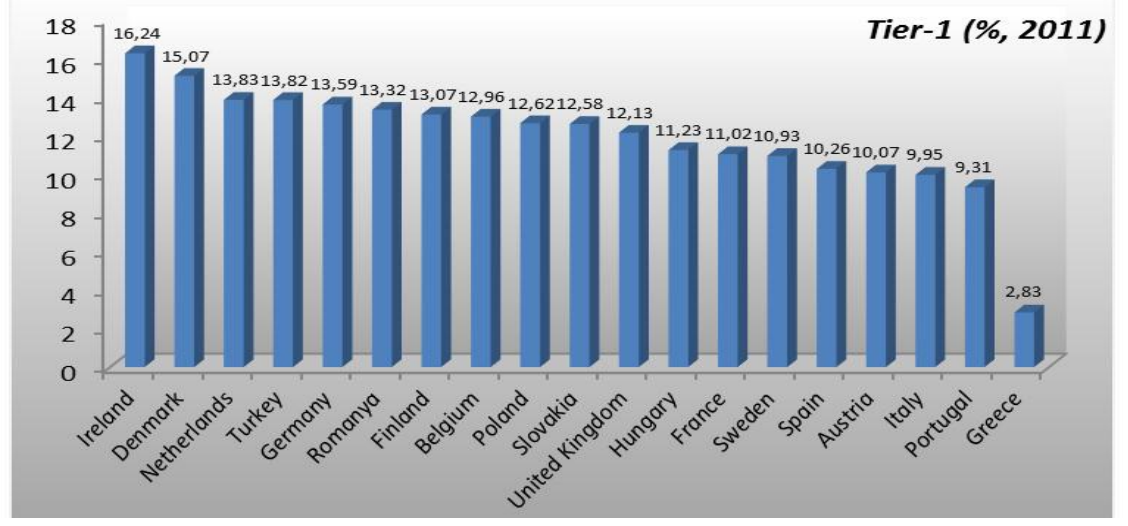

Graph 2. Tier-1 Ratios of the Countries (\%, 2011) Source: Euro Banking Association, 2013.

One of the performance indicators of the banking sector is the ratio of loan to deposit. As seen in Graph 1, this ratio, which shows the ratio of the conversion of deposits to loans, is above $100 \%$ in all the countries except Belgium, Czech Republic, Germany, Slovakia and Turkey according to the data for the year 2011.

Table 6 presents the cost to income, RoE and Interbank Market Dependence data pertaining to the banking sectors of the countries as of 2011.

As can be seen in Table 6, a priority part of the Turkish banking sector revenue is derived from consumer credits, credit cards and annual dues, which are followed by credits given to SMEs. In addition, that the number of the banks is small helps the sector to be profitable. Switching of the current structure of the Turkish banking sector into an export-oriented banking system would significantly increase the contribution of the sector to GDP.

As can be seen in Graph 2, the Turkish banking sector has a very high percentage with $13.82 \%$ (end of the year 2011) in terms of Core Capital Ratio (Tier-1). Taking into consideration that the lowest acceptable level for this ratio is $8 \%$, it is seen that the banking industry has a solid capital structure. In the Turkish banking sector, by means of the ongoing Banking Regulation and Supervision Agency (BRSA) practice aimed at limiting profit distribution and keeping profits in the body, formation of reserve fund nearly twice the total paid-in capital was achieved and the strong capital structure of the sector was preserved. In the Tier-1 Ratio ranking in the Financial Development Report published by World Economic Forum (WEF) in 2012, Turkey ranked 18th among 59 countries and outpaced many developed countries. Among the countries examined in the present study, Turkey ranked 4th after Ireland, Denmark and the Netherlands. The Banking Regulation and Supervision Board reported that this ratio is 16\% for the Turkish Banking Sector as of June 2012 (World Economic Forum, 2012).

\begin{tabular}{|c|l|c|c|l|c|}
\hline \multicolumn{3}{|c|}{ Ease of Access to Credit } & \multicolumn{3}{c|}{ Ease of Access to Loans } \\
\hline Rank & \multicolumn{2}{|c|}{ Country } & $\%$ & Rank & \multicolumn{2}{c|}{ Country } & \% \\
\hline 4 & Finland & 4.77 & 3 & Sweden & 4.56 \\
\hline 9 & Sweden & 4.58 & 8 & Finland & 4.41 \\
\hline 15 & Turkey & 4.25 & 13 & Belgium & 3.78 \\
\hline 22 & Germany & 4.14 & 16 & Netherlands & 3.74 \\
\hline 27 & Austria & 3.99 & 25 & Austria & 3.21 \\
\hline 32 & Slovak Republic & 3.75 & 26 & Germany & 3.17 \\
\hline 33 & Belgium & 3.74 & 29 & United Kingdom & 3.14 \\
\hline 36 & United Kingdom & 3.60 & 34 & Denmark & 3.09 \\
\hline 38 & Netherlands & 3.55 & 36 & Slovak Republic & 2.98 \\
\hline 39 & Poland & 3.46 & 38 & France & 2.97 \\
\hline 42 & Denmark & 3.34 & 39 & Turkey & 2.97 \\
\hline 45 & Czech Republic & 3.29 & 41 & Czech Republic & 2.88 \\
\hline 51 & Romania & 3.08 & 42 & Romania & 2.70 \\
\hline 53 & Italy & 2.94 & 46 & Poland & 2.55 \\
\hline 54 & France & 2.93 & 52 & Portugal & 2.30 \\
\hline 57 & Hungary & 2.61 & 54 & Hungary & 2.25 \\
\hline 58 & Portugal & 2.37 & 57 & Spain & 2.05 \\
\hline 60 & Ireland & 2.28 & 59 & Italy & 1.98 \\
\hline 61 & Spain & 1.97 & 60 & Ireland & 1.83 \\
\hline 62 & Greece & 1.72 & 61 & Greece & 1.71 \\
\hline
\end{tabular}

Table 7. Ranking of the Ease of Application and Access to Credit in the Countries (2011) Source: WEF, 2012. 
The Financial Development Report published by World Economic Forum (WEF) in 2012 also includes a survey on the ease of access to credit and loans in the banking sectors of 62 countries.

According to this report, while the process of access to credit is easy in Turkey, access to loans is at a low level. Most successful countries in terms of ease of access to credit and loans were Finland and Sweden (World Economic Forum, 2012). These results indicate that there are successful investments concerning SMEs and foreign investors in the respective countries and that there are no deposit deficits in these countries.

Graph 3 presents the employment data in the banking sectors of the countries as of 2011. When these data are evaluated, it becomes noteworthy that banking sector has high employment levels for Germany, United Kingdom, France and Italy. This group is followed by Spain, Turkey, Poland and the Netherlands respectively.

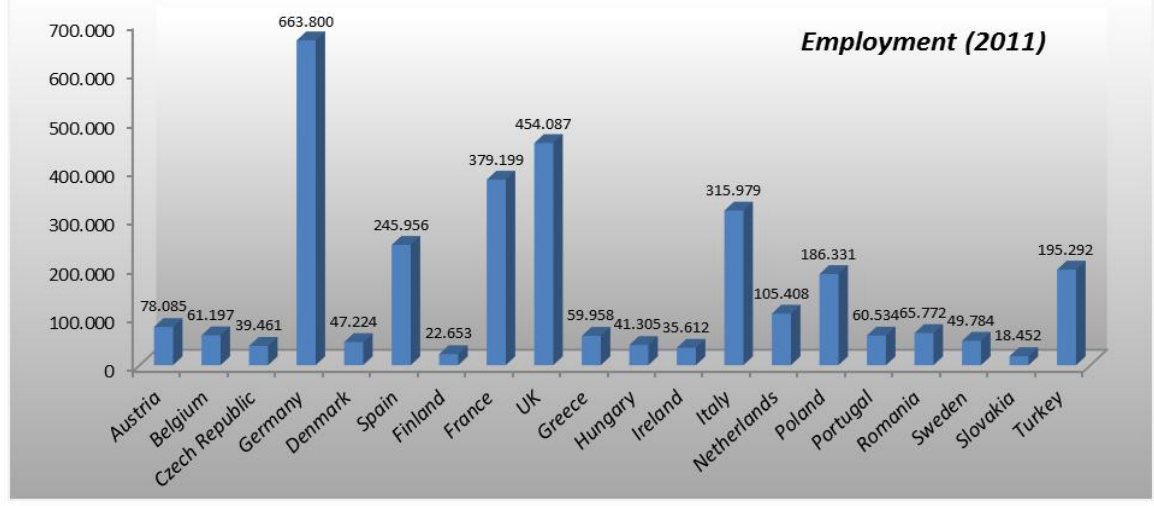

Graph 3. Level of Employment in the Banking Sector by Country Source: Euro Banking Association, 2013.

Table 8 shows the data of the countries concerning the number of Commercial Bank Branches, Debit Card Penetration and Total Number of ATMs per 100,000 adults. It is observed that Turkey is at low levels in terms of the three parameters and hence has a development potential.

According to this report, Turkish banking sector ranks 28th in terms of the number of branches, 23rd in terms of the debit card number and 38th in terms of the number of ATMs (World Economic Forum, 2012). The reasons that cause Turkey to remain at low levels in these rankings can be formulated as follows: the population of Turkey is higher than most of the countries under investigation, the number of the banks operating in Turkey is relatively low and statistics show that the banking sector is switching to internet banking.

\begin{tabular}{|c|c|c|c|c|c|c|c|c|}
\hline \multicolumn{3}{|c|}{ Commercial Bank Branches } & \multicolumn{3}{|c|}{ Debit Card Penetration } & \multicolumn{3}{|c|}{ Total Number of ATM's } \\
\hline Rank & Country & Unit & Rank & Country & $\%$ & Rank & Country & Unit \\
\hline 1 & Portugal & 75.91 & 1 & Netherlands & 97.61 & 3 & Portugal & 197.05 \\
\hline 2 & Italy & 66.86 & 2 & Sweden & 95.50 & 6 & Spain & 151.87 \\
\hline 4 & Belgium & 47.96 & 3 & Denmark & 90.13 & 10 & Germany & 116.80 \\
\hline 5 & Poland & 45.83 & 4 & Finland & 89.32 & 12 & France & 110.07 \\
\hline 6 & France & 43.11 & 5 & Germany & 88.02 & 13 & Italy & 98.56 \\
\hline 7 & Greece & 41.18 & 7 & United Kingdom & 87.58 & 16 & Ireland & 92.47 \\
\hline 8 & Denmark & 41.13 & 8 & Austria & 86.77 & 17 & Finland & 91.72 \\
\hline 9 & Spain & 39.31 & 9 & Belgium & 85.76 & 18 & Belgium & 86.37 \\
\hline 12 & Romania & 33.16 & 14 & Ireland & 70.47 & 20 & Greece & 76.72 \\
\hline 14 & Ireland & 28.63 & 15 & France & 69.25 & 22 & United Kingdom & 64.58 \\
\hline 15 & Slovak Republic & 26.50 & 16 & Slovak Republic & 68.27 & 23 & Denmark & 63.55 \\
\hline 16 & United Kingdom & 25.51 & 17 & Portugal & 68.16 & 28 & Netherlands & 58.27 \\
\hline 19 & Netherlands & 23.21 & 18 & Hungary & 62.40 & 30 & Hungary & 56.73 \\
\hline 20 & Czech Republic & 22.53 & 20 & Spain & 62.18 & 33 & Romania & 55.48 \\
\hline 27 & Germany & 17.58 & 21 & Czech Republic & 61.02 & 34 & Poland & 52.10 \\
\hline 28 & Turkey & 17.38 & 23 & Turkey & 56.64 & 35 & Slovak Republic & 50.38 \\
\hline 29 & Hungary & 16.62 & 30 & Poland & 37.34 & 36 & Austria & 48.16 \\
\hline 30 & Finland & 15.60 & 32 & Italy & 35.18 & 38 & Turkey & 43.74 \\
\hline 34 & Austria & 11.39 & 34 & Greece & 33.95 & 40 & Czech Republic & 41.65 \\
\hline 53 & Sweden & N/A & 40 & Romania & 27.71 & - & Sweden & N/A \\
\hline
\end{tabular}

Table 8. Ranking of the Average Number of Branches, Debit Card and ATMs per 100,000 adults in the Countries (2011) Source: WEF, 2012. 


\section{Comparison of the Capital Markets of the Countries}

According to the data from the World Federation of Exchange, the number of the shares traded in the main markets of the stock markets in 2012 decreased compared to 2011. It is observed that this change, which is shown in Table 9, does not apply only to Germany. A 14\% decrease in the total number of shares traded occurred also in Borsa Istanbul.

\begin{tabular}{|l|r|r|r|r|r|r|}
\cline { 2 - 7 } \multicolumn{1}{c|}{} & \multicolumn{3}{c|}{$\mathbf{2 0 1 1}$} & \multicolumn{1}{c|}{2012} \\
\hline Exchange Name & Domestic & Foreign & \multicolumn{1}{c|}{ Total } & Domestic & \multicolumn{1}{c|}{ Foreign } & \multicolumn{1}{c|}{ Total } \\
\hline NYE Spanish Exchanges & 3,241 & 35 & $\mathbf{3 , 2 7 6}$ & 3,167 & 33 & $\mathbf{3 , 2 0 0}$ \\
\hline Deutsche Börse & 969 & 143 & $\mathbf{1 , 1 1 2}$ & 939 & 134 & $\mathbf{1 , 0 7 3}$ \\
\hline Athens Exchange & 670 & 76 & $\mathbf{7 4 6}$ & 665 & 82 & $\mathbf{7 4 7}$ \\
\hline Borsa Istanbul & 269 & 3 & $\mathbf{2 7 2}$ & 262 & 3 & $\mathbf{2 6 5}$ \\
\hline Wiener Börse & 263 & 1 & $\mathbf{2 6 4}$ & 226 & 1 & $\mathbf{2 2 7}$ \\
\hline Budapest SE & 88 & 17 & $\mathbf{1 0 5}$ & 84 & 15 & $\mathbf{9 9}$ \\
\hline Irish SE & 52 & 2 & $\mathbf{5 4}$ & 51 & 1 & $\mathbf{5 2}$ \\
\hline Total & 48 & 7 & $\mathbf{5 5}$ & 42 & 8 & $\mathbf{5 0}$ \\
\hline
\end{tabular}

Table 9. The Number of Shares Traded in Exchanges (2011-2012) Source: World Federation of Exchange, 2013.

When the exchanges are classified as domestic and foreign, it is observed that BME Spanish Exchange, NYSE Euronext, Deutsche Börse and Wiener Börse are the ones where foreign companies are also traded.

When the "stock market turnover ratios" of the exchanges of the countries in Table 10 are evaluated, it is seen that many countries and primarily Turkey have high ratios and hence the speed of changing hands of shares in these exchanges is considerably high.

When Table 10 is evaluated in terms of "Stock Market Capitalization to GDP", it is seen that the capital markets with the highest contribution to the GDP of their countries are United Kingdom, Sweden and Spain. Although Turkey ranks 42nd in the overall ranking, it has outpaced many of the EU countries.

\begin{tabular}{|c|l|r|r|l|r|}
\hline \multicolumn{3}{|c|}{ Stock Market Turnover Ratio } & \multicolumn{3}{c|}{ Stock Market Capitalization to GDP } \\
\hline Rank & \multicolumn{1}{|c|}{ Country } & Value & Rank & \multicolumn{1}{c|}{ Country } & Value \\
\hline 1 & Turkey & 237.86 & 7 & United Kingdom & 129.95 \\
\hline 3 & Italy & 191.19 & 11 & Sweden & 111.98 \\
\hline 10 & Spain & 128.63 & 16 & Spain & 85.97 \\
\hline 11 & Hungary & 123.27 & 20 & Netherlands & 76.34 \\
\hline 13 & United Kingdom & 117.62 & 22 & France & 74.65 \\
\hline 14 & Germany & 114.95 & 27 & Denmark & 66 \\
\hline 17 & Finland & 109.58 & 33 & Belgium & 55.56 \\
\hline 18 & Netherlands & 108.16 & 34 & Finland & 43.11 \\
\hline 21 & Sweden & 91.67 & 35 & Germany & 40.57 \\
\hline 24 & Austria & 89.07 & 40 & Portugal & 38.66 \\
\hline 25 & France & 83.13 & 42 & Turkey & 37.12 \\
\hline 26 & Greece & 81.25 & 44 & Poland & 35.16 \\
\hline 28 & Denmark & 77.94 & 45 & Czech Republic & 24.34 \\
\hline 36 & Ireland & 58.25 & 46 & Hungary & 21.69 \\
\hline 37 & Poland & 54.03 & 48 & Greece & 20.79 \\
\hline 39 & Belgium & 47.55 & 51 & Romania & 19.09 \\
\hline 41 & Portugal & 38.72 & 53 & Austria & 15.71 \\
\hline 42 & Czech Republic & 33.66 & 54 & Italy & 15.17 \\
\hline 53 & Romania & 7.45 & 55 & Ireland & 15.1 \\
\hline 58 & Slovakia & 4.65 & 59 & Slovakia & 4.94 \\
\hline
\end{tabular}

Table 10. Stock Market Turnover Ratio ve Stock Market Capitalization to GDP Ratios of the Exchanges (2011) Source: WEF, 2012.

When the Bond Markets-GDP relationship of the exchanges of the countries in Table 11 is analyzed, it is seen that the contribution of the Private Domestic Bonds of Denmark and Ireland to GDP is high and that Turkey is at a rather low level. The reason underlying this situation is that in Turkey the private sector cannot compete with the public sector due to high rates of inflation and that the number of the companies that are able to issue bonds is considerably small. Therefore, the financing of the private sector in Turkey is realized through the banking sector. 


\begin{tabular}{|c|l|r|r|l|r|r|l|r|r|r|r|}
\hline \multicolumn{2}{|c|}{ Private Domestic Bond } & \multicolumn{3}{|c|}{ Public Domestic Bond } & \multicolumn{2}{|c|}{ Private International Bonds } & \multicolumn{3}{|c|}{ Public International Bonds } \\
\hline Rank & Country & Value & Rank & Country & Value & Rank & Country & Value & Rank & \multicolumn{1}{c|}{ Country } & Value \\
\hline 1 & Denmark & 177.0 & 2 & Italy & 88.6 & 1 & Ireland & 203.0 & 1 & Greece & 70.8 \\
\hline 2 & Ireland & 109.0 & 5 & France & 61.3 & 2 & Netherlands & 163.0 & 3 & Belgium & 29.8 \\
\hline 4 & Netherlands & 69.5 & 6 & United & 58.3 & 3 & United & 124.0 & 4 & Ireland & 26.7 \\
\hline 5 & Portugal & 67.3 & 7 & Belgium & 57.2 & 4 & Spain & 109.0 & 5 & Finland & 26.7 \\
\hline 7 & France & 54.7 & 9 & Greece & 51.0 & 5 & Portugal & 84.5 & 6 & Portugal & 26.4 \\
\hline 9 & Spain & 52.9 & 11 & Germany & 48.6 & 6 & Belgium & 82.3 & 7 & Austria & 25.1 \\
\hline 10 & Sweden & 52.4 & 12 & Portugal & 47.1 & 8 & Sweden & 71.8 & 8 & Hungary & 17.7 \\
\hline 11 & Austria & 50.9 & 13 & Netherland & 46.4 & 9 & France & 71.5 & 9 & Slovakia & 13.3 \\
\hline 12 & Belgium & 50.4 & 15 & Spain & 44.0 & 10 & Germany & 68.7 & 12 & Spain & 11.7 \\
\hline 13 & Italy & 50.0 & 16 & Hungary & 42.8 & 11 & Greece & 67.7 & 13 & Poland & 11.6 \\
\hline 16 & Greece & 32.9 & 19 & Denmark & 38.4 & 12 & Austria & 57.0 & 14 & Italy & 11.4 \\
\hline 20 & Germany & 23.3 & 20 & Poland & 36.7 & 13 & Italy & 50.3 & 17 & Germany & 8.5 \\
\hline 23 & Finland & 20.8 & 24 & Austria & 32.8 & 16 & Denmark & 41.2 & 20 & Sweden & 6.8 \\
\hline 29 & Czech & 12.3 & 28 & Ireland & 28.5 & 20 & Finland & 29.7 & 22 & Denmark & 6.2 \\
\hline 30 & United & 12.1 & 29 & Turkey & 26.9 & 28 & Hungary & 8.8 & 23 & Turkey & 5.8 \\
\hline 32 & Hungary & 5.8 & 31 & Czech & 24.6 & 34 & Czech & 6.0 & 25 & Czech & 5.5 \\
\hline 34 & Slovakia & 4.8 & 32 & Sweden & 24.4 & 47 & Turkey & 1.7 & 26 & United & 4.7 \\
\hline 36 & Poland & 2.0 & 36 & Slovakia & 20.8 & 50 & Poland & 1.2 & 29 & Netherlands & 3.4 \\
\hline 40 & Turkey & 0.6 & 42 & Finland & 11.9 & 54 & Slovakia & 0.5 & 33 & Romania & 2.6 \\
\hline 42 & Romania & 0 & 46 & Romania & 6.4 & 56 & Romania & 0 & 35 & France & 2.3 \\
\hline
\end{tabular}

Table 11. Relationship between Bond Markets and GDP (2011) Source: WEF, 2012.

When the Public Domestic Bond Market Capitalization to GDP Relationship as demonstrated in Table 11 is analyzed, it is seen that the contribution of the Public Domestic Bonds of Italy and France to GDP is high and that Turkey ranked 29th, which is a relatively high level due to fact that Turkey is a country that takes on debt through the public sector.

It is observed that Ireland and the Netherlands ranked high in terms of Private International Bonds to GDP while Turkey ranked rather low in this category.

In terms of International Bonds to GDP, Greece, which realizes public borrowing in international markets, is observed to have a high ratio while Turkey ranked 23rd, which is a relatively high ranking.

\section{Conclusion}

Turkish financial sector tends to grow in recent years. Although this growth is observed to be steady, it has not reached a sufficient volume and the sources of growth are not healthy.

That there are banks in the Turkish sector which operate in foreign countries is significant in terms of transferring resources from these countries to Turkey. For this purpose, increasing the number of branches in foreign countries should be immediately ensured by the establishment of new banks or by entering into partnership with foreign banks. Growth of volume can be achieved by transferring deposits obtained from abroad to Turkey. However, the existing banking structure in Turkey prevents the use of these opportunities. Therefore, the obstacles to the sector are required to be removed.

That the Turkish banking sector has a structure that is oriented rather towards individual consumers; that adequate and cost-effective resources cannot be fully provided for SMEs; and that SMEs face many obstacles in issuing bonds to form their own funding sources reveal a banking structure that does not overlap with the objectives of the development of the sectors in Turkey in general and with the specific objective of the development of Istanbul to become an international financial center. The Turkish banking sector has a structure that increases its profitability by deriving huge income from consumer credits, credit cards and annual dues. Changing the closed structure of the Turkish banking sector and establishing an export-oriented banking system is of great importance.

Capital markets in Turkey are observed to rank low in terms of the number of shares traded and market capitalization. It is required to implement the actions determined in order to improve the exchange, which acquired a modern structure with the establishment of Borsa Istanbul in the last two years, and to ensure that Borsa Istanbul has a competitive structure.

A further evaluation with respect to capital markets can be made for bond markets. Borsa Istanbul should support the issuance of the debt instrument of the private sector. Taking into consideration that bond issuance of the private sector depends on the decrease of the interest rates and the reduction of the borrowing of the public sector by bond issuance, reducing interest rates and the gradual withdrawal of the public sector from the bond market is important. 


\section{References}

- Banking Regulation and Supervision Agency of Turkey (BRSA), 2012. "Financial Markets Report".

- Euro Banking Association (EBA), 2012. "Euro Banking Statistics".

- Global Financial Centers Index (GFCI), 2014. "The Global Financial Centers Index 15".

- Global Financial Centers Index (GFCI), 2013. "The Global Financial Centers Index 13, 15".

- Global Financial Centers Index (GFCI), 2012. "The Global Financial Centers Index 11".

- Global Financial Centers Index (GFCI), 2011 "The Global Financial Centers Index 9".

- The Heritage Foundation, 2014. "2014 Index of Economic Freedom: Promoting Economic Opportunity and Prosperity” Eds: Terry Miller, Anthony B. Kim and Kim R. Holmes.

- World Bank \& IFC (International Financial Corporation), 2013. "Doing Business 2013 Report".

- World Bank, 2014. "Country Statistics".

- World Economic Forum (WEF), 2012. "Financial Development Report".

- World Economic Forum (WEF), 2014. "Global Competitiveness Report".

- World Federation of Exchange (WFE), 2012. "Capital Markets Statistics". 